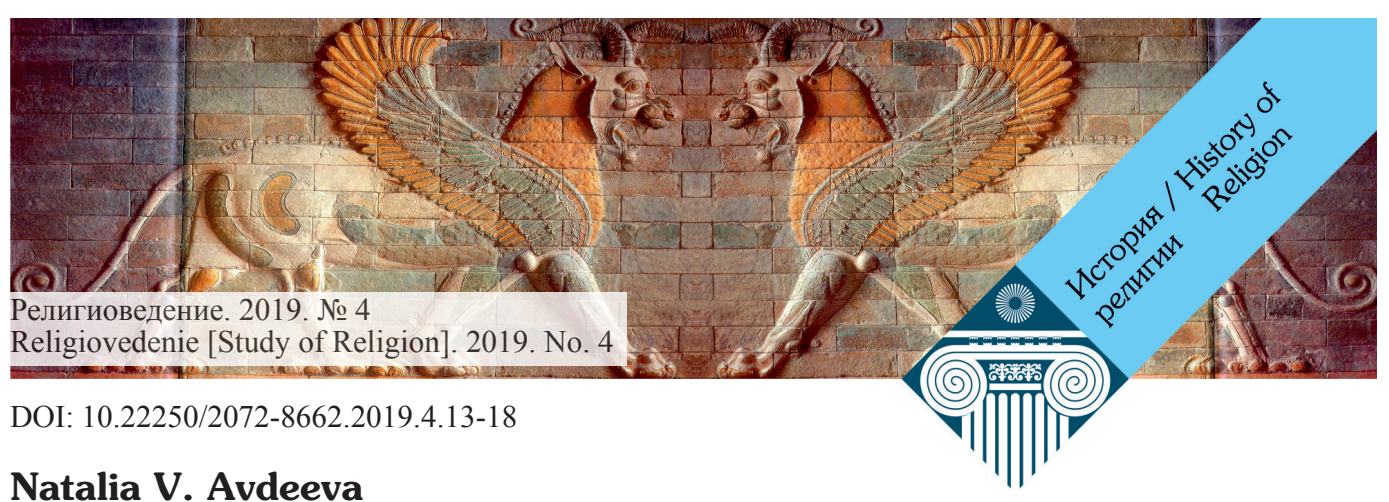

Natalia V. Avdeeva

Higher School of Economics

123 Griboedova embankment, St. Petersburg, Russia, 190068

nvavdeeva@edu.hse.ru

\title{
The Schism in the Mariavite Church of Poland
}

Abstract. The article focuses on the schism of 1920s - 1930s in the Mariavite movement. Mariavite are a Polish religious group, which was condemned by the Holy See in 1906. After the death of its founder Maria Kozłowska in 1921, Mariavitism became more Messianic, proclaiming the specific role of the Poles in the world. Mikhail Kowalski obtained an extremely high status in the Mariavite Church. He had

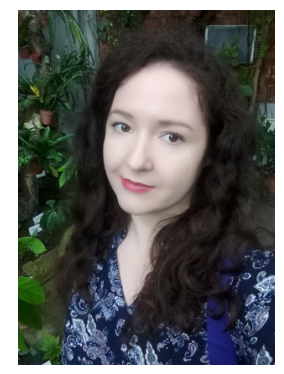

it before as well but when Kozłowska died, there was no alternative to Kowalski's power. He became the Archbishop. Kowalski made refences to the heritage of famous Polish poets and to some extent was influenced by the ideas of "the Silver age". His reforms consisted of proclamations of the exceptional position of the Polish people, who had to be an example of Christians, "mystical marriages", female priesthood and some other changings. Most of them were too radical (except for Messianism, which was appropriate for the moderate Mariavites) and were implemented too autocratically. Also, Kowalski was accused in immoral behaviour. In 1935, the majority of the Mariavites chose Filip Feldman as their new leader. The Mariavite Church lost its unity. The article is aimed at examining key aspects of the reforms. In addition, variety of Polish Catholicism is demonstrated in the article.

Key words: Catholicism, Mariavites, Old Catholics, mysticism, eschatology, messianism, Poland

Авдеева Н.В.

Высшая школа экономики

190068, Россия, г. Санкт-Петербург, набережная канала Грибоедова, 123

nvavdeeva@edu.hse.ru

\section{Раскоп в Мариавитской церкви Попьши}

Аннотация. Данная статья посвящена расколу в мариавитском движении в 1920-1930-х гг. Мариавиты - это польская религиозная группа, которая была осуждена Святым Престолом в 1906 году. После смерти основательницы мариавитизма Марии Козловской в мариавитском движении усилились мессианские настроения. Провозглашалась особая роль поляков в мире. Михаил Ковальский получил исключительно высокий статус в Мариавитской церкви. Он был влиятельным и до этого, а после смерти Козловской его власть стала безальтернативной. Ковальский принял титул архиепископа. Он ссылался на творения знаменитых польских поэтов и в определённой степени испытывал влияние идей «Серебряного века». Реформы архиепископа заключались в провозглашении исключительной роли поляков, которые должны были стать образцовыми христианами, появлении «мистических браков», женского священства и некоторых других нововведениях. Большинство из них оказались слишком радикальными (за исключением мессианизма, оказавшегося приемлемым для умеренных мариавитов). Реформы проводились в авторитарной манере. Кроме того, Ковальский был обвинён в аморальном поведении. В 1935 г. большинство мариавитов выбрало новым лидером Филипа Фельдмана. Мариавитская церковь утратила единство. В статье анализируются ключевые аспекты реформ. Кроме того, демонстрируется разнообразие польского католицизма.

Ключевые спова: католицизм, мариавиты, старокатолики, мистицизм, эсхатология, мессианизм, Польша 


\section{Introduction}

The Mariavite movement is still not a very well-known topic. This religious group emerged in a Russian part of Poland at the end of the 19th century. Its first leader was Maria Francisca (Feliksa Magdalena) Kozłowska (1862-1921). In 1893 she had a mystical experience. Kozłowska believed that she contacted with God. It led her to establishing the new group. A few young educated clerics became the first followers of the Mariavite ("Maria's life" in Latin) movement. The community criticized the official Catholic clergy, promoted mysticism, the cult of the Blessed Virgin and the icon "Our Lady of Perpetual Help", the extremely high status of Kozłowska, social work.

The Mariavites visited Rome, they intended to get a permission for establishing a legal Mariavite community inside the official Church. These plans failed [Rybak, 1992]. The main reason of the condemnation was the reduction of the official Church's power. Also, the context of this period was extremely important: The Catholic Church was in a crisis, and every hot discussion could be seen as an exceptional danger. It probably was also a conflict of generations (the leaders of the Mariavite priests were rather young).

In 1906, Pius X cursed the Mariavite movement in the encyclical "on the Mariavites or mystic priests of Poland" [Pius X]. The group became a part of the Old Catholic Union in 1909. Maria Kozłowska was a "spiritual leader", while Kowalski became a bishop.

After Kozłowska's death in 1921, her successor Kowalski started reforms, breaking traditional Catholic canons. The majority of the Mariavites were not ready for such measures. The Mariavite leader did not tolerate any opposition and after a series of conflicts, the Mariavite movement divided.

There are some works on the schism in Mariavitism, written by Polish authors. In general, the papers contain mentions, overviews or references of many sources, and they are useful for a preliminary work or adding new information [Łojek, 2001, Rybak, 1992, Mames, 2009].

The book of Jerzy Peterkiewicz, "The Third Adam" [Peterkiewicz, 1975] is the only one huge work about Mariavitism in English. In general, it deals with the emergence of the radical Mariavites, who accepted Kowalski's reforms and were loyal to him despite the imprisoning and the schism. The best part of this paper is tracing of Kowalski's reforms in the context of the Russian culture of this period. At the same time, the book has disadvantages. It lacks coherency and research analysis. The author was not a historian or an anthropologist, and the usage of the sources was not efficient enough. He was too fascinated with occasional coincidences, not relevant for the topic or scandal details of sexual life of the Mariavites.

In his collection of essays, Tomasz Dariusz Mames pays attention to the Mariavites in other countries (such as France or the Great Britain), writes about some features of the Polish Republic, the Old Catholic Churches in Poland, uses many sources [Mames, 2009]. He supposes that Kowalski's views could be influenced by Thomas Moore and St. Augustine but does not provide evidence [Mames, 2009, 117, 126].

\section{Kowalski's views in the context of Apocalypticism and Polish messianism}

After Kozłowska's death, Kowalski became even more powerful than he was earlier. He became the only one Archbishop of the Mariavite Church. He was a key interpreter of Kozłowska's writings and concentrated all branches of the Mariavite organization in his hands, including the Ecclesiastical court [Staro-katolicki Kośćiół Mariawitów, 1923, 1-4].

Maria Kozłowska's writings predicted the end of the world because of immorality of the clergy and lack of belief. When Kowalski became the only Mariavite leader, he held this view. Moreover, for him the Polish nation was put above others in the spiritual dimension, presenting piety, possibility to form a perfect society, "the Divine Kingdom on earth".

"The main basics of Mariavitism, announced in the Apocalypse and predicted in the works of the thinkers and the poets-prophets of the Polish people", "The pastoral letter about binding of Satan" [Kowalski, 1923, Kowalski, 1929] are representative examples of the Mariavite Apocalyptic literature in this period.

In "The main basics of Mariavitism, announced in the Apocalypse" Kowalski briefly mentioned the Marian apparition in La Salette (1846, France) and Melania Calvat's prophesies as a preparatory step for Kozłowska's mystical experience [Kowalski, 1923, 11]. 


\section{История религии / History of Religion}

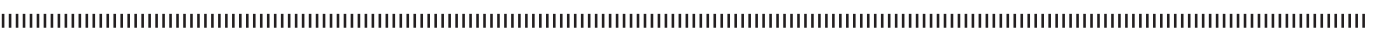

Other and more important precursors were poets and mystics, especially Polish, such as Adam Mickiewicz (1798-1855), Juliusz Słowacki (1809-1849) and Zygmunt Krasiński (1813-1859) [Kowalski, 1923, 4], the most famous Polish Romantic poets.

Mickiewicz really demonstrated Messianic views, combined with anti-clericalism. It is worth keeping in mind that in the first half of the nineteenth century the Catholic Church accepted partitions of Poland. This factor affected the poet [Bukowczyk, 1985, 12].

Also, Kowalski made reference to Andrzej Towiański (1799-1878) [Kowalski, 1923, 49, 64-69], who proclaimed himself a new messiah of the Divine Kingdom, and such proclamations led to the conflict with Rome [Porter, 2003, 215-216]. Earlier, Catholic Modernist M. Zdzechowski in his paper about Polish religiosity (1915), wrote about Towiański positively because he put "consciousness upon authority and thus was a predecessor $<\ldots>>$ of the modernist movement" [Zdzekhovskij, 1915, 23].

Other mentioned Polish authors also had Messianic views or deviated from the official Catholicism. For example, Józef Maria Hoene-Wroński (1776-1853) was a mathematician, combining scientific knowledge and religion [Murawski, 2006, 143-150]. Maria Konopnicka (1842-1910) was a writer and a poet. Her writings were influenced by Mickiewicz and Słowacki [Biliński, 2015, 73]. Concerning religion, she was rather liberal and her views could even become similar with Baruch Spinoza's pantheism [Biliński, 2015, 76].

Examining Mariavite press of the early period (the 1900-s), mentions of Mickewicz and Krasiński were founded but the interpretation of their texts differentiated from later Mariavite papers.

The parts of the text "Maryawityzm Mickewicza" ("Mariavitism of Mickewicz") were published in five issues of "Mariavite news" [Wiadomości, 1909a, 153-155; Wiadomości, 1909b, 169-171; Wiadomości, 1909c, 185-187; Wiadomości, 1909d, 233-235; Wiadomości, 1909e, 249-252]. They did not contain a proclamation of Polish Messianism. The anonymous author (probably, it was Kowalski) quoted rather "general" comments about problems in the Catholic Church, importance of a deep faith, waiting for new ideals of people and so on. In addition, Mickewicz called Napoleon "the most wonderful" person of his time, whose "inner work" was more impressive than attempts of the clergy or the Pope [Maryawityzm, 1909a, 154]. Positive opinions and even the "cult" of Napoleon became popular among the Poles, who hoped to obtain independence for their country with his help [Gonchar, 2009, 99-107].

Also, in the text about problems of Polish Catholicism ("the Mariavite news", 1910), Zygmunt Krasiński was not mentioned in any optimistic Messianic context. On the contrary, there was a letter to his father about "vanity and imitation" among the Poles, and the Mariavite author agreed with this statement, adding that it could be applied in the religious sphere [Katolicyzm, 1910, 201].

The key point of the book "The main basics of Mariavitism" was to demonstrate that the emergence of Mariavitism was predicted by many people. But the author not only put Mariavitism as a key and final point in history, he went further, proclaiming Kozłowska "The Woman clothed in the Sun", described in the Apocalypse. Traditionally, this woman is interpreted as the Holy Virgin or the Holy church. According to Kowalski, the Polish nation was chosen by God, and Kozłowska was "The Beloved", "The Wife", "a perfect priest", whose birth was expected by the Polish poets or mystics [Kowalski, 1929, 2].

In addition, Kowalski translated the Old Testament, the New Testament, and Dante's "Divine Comedy" in Polish. These works were not the first translations of the Bible and "The Divine Comedy" [Enholc-Narzynska, 1963, 133-138; Zbierańska, 1966, 56-61]. In 1933, Kowalski even wrote a poem "Beatrice" [Peterkiewicz, 1975, 234]. In this text, Kozlowska was named as this hero of Dante's masterpiece, but the plot of the poem, published after the schism, was different from Dante's text.

After examining the sources, it is possible to agree with Peterkiewicz in the point that this narrative of a woman who is very near to the Divine, and probably is not a human being but some supernatural person, can be defined as one more implementation of socalled the Beautiful Lady or the Eternal Feminine [Peterkiewicz, 1975]. This concept gained popularity in many countries, including the Russian Empire during Fin de siècle. When Kowalski studied in the Ecclesiastical Academy of Saint-Petersburg [Rybak, 1992], 


\section{История религии / History of Religion}

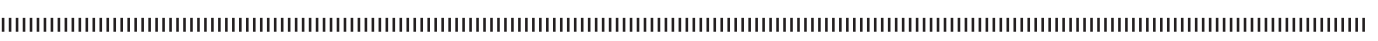

he spoke Russian, and could read contemporary Russian literature, or easily make contacts with people, fascinated by the Symbolist movement in Art and Literature ("the Silver Age", coming after the "Golden Age" of the nineteenth century's Russian Literature).

In 1924, Kowalski abolished celibacy of the clergy and nuns. He postulated necessity of "mystical marriages" between them. The Prioress Antonina Maria Izabella Wiłucka (1890-1946) became his wife in 1922 [Rybak, 1992].

In 1930, he published the paper about "the universal priesthood", stating that "Jesus wants that Mariavite families would become priest families" [Ku Królestwu Bozemu, 2009, 328]. The doctrine of "the universal priesthood" is Protestant. In addition, Jerzy Peterkiewicz noted influence of Russian religious thinkers Dmitrij Merezhkovsky (1866-1941) and Vasilij Rozanov (1856-1919) on Kowalski in the issue of religiosity and sexuality: they wanted to combine them [Peterkiewicz, 1975, 57].

In 1929, the Mariavite leader postulated that women could become priests, bishops and archbishops. Of course, the reform contradicted with the Catholic canons. Kowalski responded in his letters that the Virgin Mary was the first female priest, and although the Bible did not depict any female clergy, it did not contain a restriction of it as well [Lojek, 2001, 41-42]. Kowalski mentioned deaconesses among the early Christians; according to him, the Mariavite Church, which was chosen by God, could establish new rules as it was written in the Book of Revelation [Ku Królestwu Bozemu, 2009, 263].

In 1928, Kowalski issued instructions about the size of land, which could be not more than 30 mórgs (one Polish mórg was approximately 0,56 hectare) for one, if it was bigger it had to be given to their relatives or to poor people. Also, in this pastoral letter he wrote about compulsory literacy, female modesty, prohibition of smoking and drinking vodka [Ku Królestwu, 2009, 256].

Many Mariavites denied most of the innovations, introduced by Kowalski. However, the moderate Mariavites" "Relation of the Old Catholic Mariavite Church to the Polish state", demonstrated Messianic views as well. They wrote: "the Mariavites as well as Polish Messianists believe that Poland has to perform the mission of the implementation of the Kingdom of God on earth...'[AAN, Fund 2/14/0, Inventory 5, File 1433, fol. 61-63].

It is possible to define this very optimistic attitude towards human history, implying the implementation of 'the Divine Kingdom on earth' as a postmillenarism doctrine. Millenarism (Latin words "one thousand" and "year") means believing of the Second Coming of Christ for one thousand years and a happy, pious kingdom of God. Such hopes are driven by people's dreams of a better, right world. Postmillenarism implies that this kingdom will come before the Second Coming.

It should be mentioned, problems in the Polish economy of this period could to some extent increase Apocalyptic and Messianic moods among the Mariavites. Poland faced the Great Inflation and the Great Depression [Porter, 2014, 105-125]. People could be disappointed with the situation in Poland, which returned its independence but failed to be effectively modernized.

\section{The schism in the Mariavite Church after the radical reforms}

In 1923, there was the first phase of the schism. Some of the Mariavites including priests Józef Pągowski, Ludwik Rytel, Jan Modrzejewski, Tomasz Krakiewicz, Edward Marks and Zenon Suchoński leaved the Mariavite movement because they did not accept the doctrine of "mystical marriages". Marks, Modrzejewski and some parishioners came back to the Catholic Church [Rybak, 1992] Józef Pągowski established an independent Old Catholic group. In his open letter (1923) about Kowalski, he mentioned that he already had seen his "bad tendencies" [Lojek, 2001, 64-65].

One of the most important results of the reforms became a trial on Kowalski. In 1928-1929, Kowalski was accused in "immoral behavior". It meant that the Mariavite leader molested some Mariavite girls and women (including underage girls). The supposed period of imprisonment was changing (2-4 years) [Rybak, 1992].

Bishop Klemens Maria Filip Feldman became the key opponent of Kowalski. In 1935, on the meeting of the Mariavites in Płock, the majority decided that Kowalski became "a despot", "a new Pope", his reforms were inappropriate and he had to resign [AAN, Fund 2/14/0, Inventory 5, File 1433, fol. 7]. Kowalski tried to prevent organizing this council of the dissidents, occupying the church buildings, which were his property. 


\section{История религии / History of Religion}

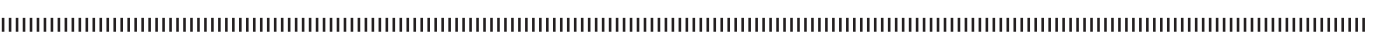

In the result, the council was held in the monastic theater [AAN, Fund 2/14/0, Inventory 5, File 1433, fol. 7].

The consequence of the split became dividing of the Mariavite church on two groups. The biggest was the group of Feldman (the Old Catholic Mariavite Church), canceling Kowalski's reforms, including the female clergy. The rest of the Mariavites chose the Catholic Mariavite Church.

\section{Бибпиографический список}

1. Гончар, С.В. Адам Мицкевич и миф Наполеона в польской литературе XIX века / C.В. Гончар // Творчество Адама Мицкевича и современная мировая культура: сборник научных работ. - Гродно, 2010. - С. 99-107.

2. Здзеховский, М. О польском религиозном сознании / М. Здзеховский. - Москва: тип. т-ва И.Д. Сытина, 1915. - 36 с.

3. Archiwum Akt Nowych (AAN). Fund 2/14/0. Inventory 5. File 1433. Fol. 7.

4. Archiwum Akt Nowych (AAN), Fund 2/14/0. Inventory 5. File 1433. Fols. 61-63.

5. Biliński, K. Motywy biblijne we wczesnej twyrczości Marii Konopnickiej / K. Biliński // Acta Universitatis Wratislaviensis, Prace Literackie LV. - 2015. - № 36/79. - P. 71-94.

6. Bukowczyk, J. Mary the Messiah: Polish Immigrant Heresy and the Mal-leable Ideology of the Roman Catholic Church, 1880-1930 / J. Bukowczyk // Journal of American Ethnic History. 1985. - Vol. 4. - № 4. - P. 5-32.

7. Enholc-Narzynska, B. The Polish Translations of the Bible / B. Enholc-Narzynska // Bible Translator. - 1963. - № 14.3. - P. 133-138.

8. Górecki, A. Mariawici i mariawityzm - narodziny i pierwsze lata istnienia / A. Górecki. Warszawa: Wydawnictwo DIG, 2011. - 426 p.

9. Katolicyzm polski // Wiadomości Maryawickie. - 1910. - № 26. - P. 201-202.

10. Kowalski, J.M. Główne podstawy mariawityzmu objawione w Apokalipsie i zapowiedziane w dziełach myślicieli i wieszczów narodu polskiego / J.M. Kowalski. - Płock: Wydawnictwo Maryawitów, 1923. - 238 p.

11. Kowalski, J.M. List pasterski N.O. Arcybiskupa Marjawitów o związaniu szatana // J.M. Kowalski. - Felicyanów, 1929. - 4 p.

12. Ku Królestwu Bozemu. Felicjanów: Wydawnictwo Kościoła Katolickiego Mariawitów, 2009. - 435 p. 13. Łojek, K. Rozłam w łonie Starokatolickiego Kościoła Mariawitów w 1935 roku: studium historyczne / K. Łojek. - Warszawa: Europejskie Kolegium Edukacji, 2001. - 151 p.

14. Mames, T.D. Mysteria mysticorum: szkice z duchowości i historii mariawitów / T.D. Mames. Kraków: Nomos, 2009. - 268 p.

15. Maryawityzm Mickewicza // Wiadomości Maryawickie. -1909. - № 20. - P. 153-155.

16. Maryawityzm Mickewicza // Wiadomości Maryawickie. -1909. - № 22. - P. 169-171.

17. Maryawityzm Mickewicza // Wiadomości Maryawickie. -1909. - № 24. - P. 185-187.

18. Maryawityzm Mickewicza // Wiadomości Maryawickie. - 1909. - № 30. - P. 233-235.

19. Maryawityzm Mickewicza // Wiadomości Maryawickie. - 1909. - № 32. - P. 249-252.

20. Murawski, R. The Philosophy of Hœne-Wroński / R. Murawski // Organon. - 2006. - № 35. P. $143-150$.

21. Peterkiewicz, J. The Third Adam / J. Peterkiewicz. - London: Oxford University Press, 1975. $243 \mathrm{p}$.

22. Pius X. On the Mariavites or mystic priests of Poland [Электронный pecypc] / Pius X // The Holy See. - URL: http://w2.vatican.va/content/pius-X/en/encyclicals/documents/hf_p-x_ enc 05041906 tribus-circiter.html (дата обращения 28.03.2019).

23. Porter, B. Thy Kingdom come Patriotism and Prophecy in 19th Century Poland / B. Porter // Catholic Historical Review. - 2003. - № 89.2 - P. 215-216.

24. Porter, B. Poland in the Modern World: Beyond Martyrdom / B. Porter. - Chichester: WileyBlackwell, 2014. - $390 \mathrm{p}$.

25. Rybak, S. Mariawityzm. Studium historyczne [Электронный ресурс] / S. Rybak. // Warszawa:

1992. Parafia Kościoła Starokatolickiego Mariawitów w Warszawie. - URL: http://web.archive. org/web/20070930003322/http://www.mariawita-warszawa.com/content/media/ksiazka_mar/ Ksiazka\%20Mariawityzm\%20WWW.PDFp.4 (дата обращения 17.11.2018).

26. Staro-katolicki Kościół Mariawitów. - Płock: Wydawnictwo Maryawitów, 1923. - 40 p.

27. Zbierańska, K. Dante in Poland: A retrospect / K. Zbierańska // The Polish Review. - Vol. 11. № 3. - P. 56-61. 


\section{История религии / History of Religion}

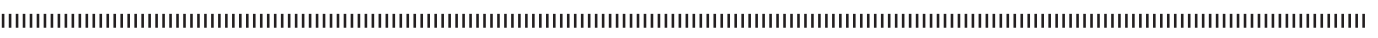

\section{References}

1. Biliński K. University Acts of Bratislava, Literary Work LV [Acta Universitatis Wratislaviensis, Prace Literackie LV]. 2015, no. 36\79, pp. 71-94 (in Polish).

2. Bukowczyk J. Mary the Messiah: Polish Immigrant Heresy and the Malleable Ideology of the Roman Catholic Church, 1880-1930. Journal of American Ethnic History, 1985, vol. 4, no. 4, pp. 5-32.

3. Enholc-Narzynska B. The Polish Translations of the Bible. Bible Translator, 1963, no.14.3, pp. 133138.

4. Górecki A. The Mariavites and Mariavitism - the Birth and Early Years of Existence [Mariawici i mariawityzm - narodziny i pierwsze lata istnienia]. Warszawa: Wydawnictwo DIG, 2011, 426 p. (in Polish).

5. Gonchar S.V. Adam Mitskevich i mif Napoleona v polskoi literature XIX veka [Adam Mickiewicz and the Myth of Napoleon in Polish Literature of the 19th Century]. Grodno: Lamark, 2010, pp. 99-107 (in Russian).

6. Kowalski J.M. The Main Basics of Mariavitism, Announced in the Apocalypse and Predicted in the Works of the Thinkers and the Poets-Prophets of the Polish People [Główne podstawy mariawityzmu objawione w Apokalipsie i zapowiedziane w dziełach myślicieli i wieszczów narodu polskiego]. Płock: Wydawnictwo Maryawitów, 1923, 238 p. (in Polish).

7. Kowalski J.M. The Pastoral Letter of the Archbishop of the Mariavites about Binding of Satan [List pasterski N. O. Arcybiskupa Marjawitów o związaniu szatana]. Felicyanów, 1929, 4 p. (in Polish).

8. Łojek K. Rozłam w tonie Starokatolickiego Kościoła Mariawitów w 1935 roku:studium historyczne [The Split of the Old Catholic Mariavite Church in 1935: A Historical Study]. Warszawa: Europejskie Kolegium Edukacji, 2001,151 p. (in Polish).

9. Mames T.D. The Mysteries of the Mystics: Essays about the Spirituality and History of the Mariavites [Mysteria mysticorum: szkice z duchowości i historii mariawitów]. Kraków: Nomos, 2009, 268 p. (in Polish).

10. Mariavitism of Mickewicz [Maryawityzm Mickewicza]. Wiadomości Maryawickie, 1909, no. 20, pp. 153-155 (in Polish).

11. Mariavitism of Mickewicz [Maryawityzm Mickewicza]. Wiadomości Maryawickie, 1909, no. 22, pp. 169-171 (in Polish).

12. Mariavitism of Mickewicz [Maryawityzm Mickewicza]. Wiadomości Maryawickie, 1909, no. 24, pp. 185-187 (in Polish).

13. Mariavitism of Mickewicz [Maryawityzm Mickewicza]. Wiadomości Maryawickie, 1909, no. 30, pp. 233-235 (in Polish).

14. Mariavitism of Mickewicz [Maryawityzm Mickewicza]. Wiadomości Maryawickie, 1909, no. 32, pp. 249-252 (in Polish).

15. Murawski R. The Philosophy of Hone-Wroński. Organon, 2006, no. 35, pp. 143-150.

16. Peterkiewicz J. The Third Adam. London: Oxford University Press, 1975, 243 p.

17. Pius X. On the Mariavites or mystic priests of Poland. The Holy See. Available at: http://w2.vatican. $\mathrm{va} /$ content/pius-X/en/encyclicals/documents/hf_p-x_enc_05041906_tribus-circiter.html (accessed: March 28, 2019).

18. Polish Catholicism [Katolicyzm polski]. Wiadomości Maryawickie, 1910, no. 26, pp. 201-202 (in Polish).

19. Porter B. Thy Kingdom come Patriotism and Prophecy in 19th Century Poland. Catholic Historical Review, 2003, no. 89.2, pp. 215-216.

20. Porter B. Poland in the Modern World: Beyond Martyrdom. Chichester: Wiley-Blackwell, 2014, 390 p.

21. Rybak S. Mariavitism. A historical study [Mariawityzm. Studium historyczne]. Warszawa: 1992 [Parafia Kościoła Starokatolickiego Mariawitów w Warszawie] Available at: http://web.archive.org/ web/20070930003322/http://www.mariawita-warsza-wa.com/content/media/ksiazka_mar/Ksiazka\%20 Mariawityzm\%20WWW.PDFp.4 (accessed: November 17, 2018) (in Polish).

22. The Archive of New Acts [Archiwum Akt Nowych, (AAN)]. Fund 2/14/0, inventory 5, file 1433, fol. 7 (in Polish).

23. The Archive of New Acts [Archiwum Akt Nowych, (AAN)]. Fund 2/14/0, inventory 5, file 1433, fols. 61-63 (in Polish).

24. The Old Catholic Mariavite Church [Staro-katolicki Kośćiół Maria-witów]. Płock: Wydawnictwo Maryawitów, 1923, 40 p. (in Polish).

25. To the Kingdom of God [Ku Królestwu Bozemu]. Felicjanów: Wydawnictwo Kościoła Katolickiego Mariawitów, 2009, 435 p. (in Polish)

26. Zbierańska K. Dante in Poland: A Retrospect. The Polish Review, vol. 11, no. 3, pp. 56-61.

27. Zdzekhovskij M.E. O pol'skom religioznom soznanii [About Polish Religious Consciousness]. Moscow: I.D. Sytin Publ., 1915, 36 p. (in Russian). 